\title{
Diversidade genética de isolados de Mycosphaerella musicola obtidos de bananais do norte de Minas Gerais, Brasil por meio de marcadores RAPD
}

\author{
Genetic diversity of Mycosphaerella musicola isolates obtained from bananas of north of \\ Minas Gerais, Brazil by using RAPD markers
}

\author{
Janaína Ribeiro Oliveira ${ }^{\mathrm{I}}$ Silvia Nietsche ${ }^{\mathrm{I}}{ }^{*}$ Márcia Regina Costa $^{\mathrm{II}}$ Edson Hiydu Mizobutsi ${ }^{\mathrm{II}}$ \\ Dario Alves de OliveiraII
}

\section{RESUMO}

\begin{abstract}
Onze primers RAPD foram utilizados para avaliar a variabilidade genética de 31 isolados de M. musicola coletados a partir de folhas de bananeiras 'Prata Anã' e 'Nanica', cultivadas no Norte de Minas Gerais. Foram amplificados um total de 83 bandas sendo 73 polimórficas, dando uma média de 6,6 bandas polimórficas por primer. As distâncias genéticas observadas variaram de 0,56 a 0,06 entre os isolados, com distância média de 0,25. O dendrograma construído com base no método UPGMA revelou a formação de 8 grupos, não sendo observada correlação entre a diversidade genética dos isolados e as origens geográficas dos isolados avaliados.
\end{abstract}

Palavras-chave: Sigatoka amarela, 'Prata Anã', Musa spp., variabilidade.

\section{ABSTRACT}

Eleven primers RAPD were used to estimate the genetic variability between 31 isolates of $\boldsymbol{M}$. musicola collected from 'PrataAnã' and Nanica bananas that were cultivated in northern Minas Gerais, Brazil. A total o 83 fragments were amplified, of which 73 were polymorphic, corresponding to an average of 6.6 polymorphic fragments per primer. The genetic distances ranged from 0.06 to 0.56 and the average distance of 0.21. A dendrogram constructed based on the UPGMA clustering method revealed 8 and no correlation between molecular grouping and geographical origin was observed.

Key words: Sigatoka leaf spot, 'Prata Anã', Musa spp., variability.

A produção mundial anual de bananas e plátanos está estimada em 400 milhões de toneladas, o
Brasil é o quarto maior produtor, com 7.193 mil toneladas, sendo Minas Gerais responsável por 8,6\% da produção nacional (FAO, 2009). A bananicultura no norte do estado de Minas Gerais desenvolve-se basicamente sob irrigação em um clima tropical semiárido. Na região, o controle da Sigatoka amarela é realizado essencialmente pela aplicação de fungicidas sistêmicos (RODRIGUES et al., 2011).

Essa enfermidade é causada pela espécie fúngica Mycosphaerella musicola Leachex Mulder (Pseudocercospora musae, forma anamórfica) (JONES, 2003). O patógeno causa a morte prematura das folhas, o que resulta na redução da capacidade fotossintética e, por consequência, na redução do número de pencas e do tamanho dos frutos, do amadurecimento precoce e desuniformidade deles, promovendo perdas de até 50\% (CORDEIRO et al., 2005).

Relatos sobre a diversidade genética das espécies M. musicola e M. fijienses por meio de diferentes marcadores moleculares têm sido publicados (CARLIER et al., 1996, RIVAS et al., 2004, HALKETT et al., 2010). A quantificação da diversidade genética de fungos patogênicos auxilia no planejamento de estratégias mais eficazes que venham a maximizar o desenvolvimento de variedades resistentes, pois gera informação sobre o nível e distribuição da variabilidade dos isolados existentes em uma população ou região (CARLIER et al., 2003). Esses estudos podem auxiliar no manejo local da doença bem como no incremento

'Programa de Pós-graduação em Ciências Agrárias, Universidade Federal de Minas Gerais (UFMG), Montes Claros, MG, Brasil.

"IPrograma de Pós-graduação em Produção Vegetal no Semiárido, Universidade Estadual de Montes Claros (UNIMONTES), Reinaldo Viana 2630, 39440-000, Janaúba, MG, Brasil. E-mail: silvia.nietsche@unimontes.br. *Autor para correspondência. 
da eficiência dos programas de melhoramento, visando à resistência a doença (PEREA et al., 2005).

No presente estudo, marcadores moleculares do tipo RAPD foram utilizados com o objetivo de analisar a variabilidade genética existente entre isolados de $\boldsymbol{M}$. musicola coletados no Norte de Minas Gerais.

Isolados de M. musicola foram obtidos a partir de folhas de bananeiras, 'Prata Anã' (AAB) e 'Nanica' (AAA), coletadas em pomares comerciais localizados em diferentes municípios da região norte do estado de Minas Gerais (Tabela 1). A região caracteriza-se por apresentar temperatura média anual de $24^{\circ} \mathrm{C}$ e precipitação média anual de 1.400 a $600 \mathrm{~mm}$. O sistema de irrigação localizado é do tipo microaspersão e o controle da Sigatoka amarela é realizado por meio do controle químico (estrobirulinas e triazois), durante o períodode dezembro, quando se iniciam as primeiras chuvas, e estendendo-se até o final de abril. As pulverizações são realizadas com intervalos de 45 dias, totalizando uma média de três a quatro pulverizações ao ano. Todos os isolados foram obtidos a partir de isolamento monospórico. ODNA de cada isolado foi extraído por meio do protocolo de extraçãoproposto por DOYLE \&DOYLE(1990), modificado porFALEIROet al. (2004).

As análises de RAPD foram conduzidas por meio do uso de 11 primers tomados ao acaso (OPC12, OPE04, OPE07, OPB09, OPA01, OPAP 07, OPAP 08, UBC 12, UBC 41, UBC 43, UBC 54, que geraram 6, 2, 8, $4,7,8,8,6,7,6$ e 11 bandas polimórficas, respectivamente). $\mathrm{O}$ volume final da reação foi de $25 \mu \mathrm{L}$, contendo Tris/ $\mathrm{HCl} 10 \mathrm{mM}, \mathrm{KCl} 50 \mathrm{mM}, \mathrm{MgCl}_{2} 2 \mathrm{mM}$,
$100 \mu \mathrm{M}$ de cada desoxinucleotídeo, $0,4 \mu \mathrm{M}$ de primer, 0,2 unidade de Taq DNA Polimerase, 50ng de DNA de Mycosphaerella musicola e água ultra pura para completar $25 \mu \mathrm{l}$. As amplificações foram realizadas em termociclador Eppendorf, modelo MASTER CYCLER personal 5332, sob as seguintes condições: 40 ciclos de $94^{\circ} \mathrm{C} / 30$ segundos, $35^{\circ} \mathrm{C} / 30$ segundos e $72^{\circ} \mathrm{C} / \mathrm{um}$ minuto e um ciclo ao final de $72^{\circ} \mathrm{C}$ por sete minutos. Os produtos da amplificação foram separados em gel de agarose 1,2\% em tampão TBE 1X. As análises de divergência genética e de agrupamento foram realizadas com o auxílio do programa GENES (CRUZ, 2001). Foi calculado o valor cofenético entre a matriz de distâncias genéticas e a matriz dos valores cofenéticos, para verificar a consistência do agrupamento, bem como pelo procedimento de reamostragem utilizando 1.000 booststraps.

A presença de polimorfismo em todos os primers testados indica a presença de alta variabilidade genética entre os isolados avaliados. No total, foram obtidas 73 bandas polimórficas, dando uma média de 6,6 bandas polimórficas por primer. Foi observada média de 0,91 banda monomórfica por primer. As distâncias genéticas observadas variaram de 0,56 a 0,06 (matriz de distância genética,dados não apresentados) entre os isolados, com distância média de 0,21. As menores distâncias foram observadas entres os isolados IsJ 3 e IsFS 1, IsE 2 e IsP 2, IsU 2 e IsE 4 e IsFS 4 e IsU 2, sendo que todos apresentaram somente 0,06 de distância genética (grau de similaridade de 94\%). Nota-se que os isolados que apresentaram as menores distâncias não são oriundos de um mesmo local de

Tabela 1 - Identificação, procedência e origem de 31 isolados de $\boldsymbol{M}$. musicola coletados a partir de folhas das cultivares 'Prata Anã' e 'Nanica', Minas Gerais, Brasil.

\begin{tabular}{|c|c|c|c|c|c|}
\hline Isolado & Município & Cultivar & Isolado & Município & Cultivar \\
\hline IsJ 1 & Janaúba & 'Prata Anã' & IsV 1 & Verdelândia & 'Prata Anã' \\
\hline IsJ 2 & Janaúba & 'Prata Anã' & Is V 2 & Verdelândia & 'Prata Anã' \\
\hline IsJ 3 & Janaúba & 'Prata Anã' & IsV 3 & Verdelândia & 'Prata Anã' \\
\hline IsJ 4 & Janaúba & 'Prata Anã' & IsV 4 & Verdelândia & 'Prata Anã' \\
\hline IsJ 5 & Janaúba & 'Prata Anã' & IsFS 1 & Francisco Sá & 'Prata Anã' \\
\hline IsJ 6 & Janaúba & 'Prata Anã' & IsFS 2 & Francisco Sá & 'Prata Anã' \\
\hline IsU 1 & Urandi & 'Prata Anã' & IsFS 3 & Francisco Sá & 'Prata Anã' \\
\hline IsU 2 & Urandi & 'Prata Anã' & IsFS 4 & Francisco Sá & 'Prata Anã' \\
\hline IsU 3 & Urandi & 'Prata Anã' & IsNP 1 & Nova Porteirinha & 'Prata Anã' \\
\hline IsP 1 & Porteirinha & 'Prata Anã' & IsCE 1 & Capitão Enéas & 'Prata Anã' \\
\hline IsP 2 & Porteirinha & 'Prata Anã' & IsMC 1 & Matias Cardoso & 'Nanica' \\
\hline IsE 1 & Espinosa & 'Prata Anã' & IsMC 2 & Matias Cardoso & 'Prata Anã' \\
\hline IsE 2 & Espinosa & 'Prata Anã' & IsMC 3 & Matias Cardoso & 'Nanica' \\
\hline IsE3 & Espinosa & 'Prata Anã' & IsMC 4 & Matias Cardoso & 'Prata Anã' \\
\hline IsE 4 & Espinosa & 'Prata Anã' & IsSL 1 & Sebastião Laranjeiras & 'Prata Anã' \\
\hline IsE 5 & Espinosa & 'Prata Anã' & - & - & - \\
\hline
\end{tabular}


coleta. A maior distância genética foi observada entre os isolados IsU 2 e IsV 1 com 0,56 (grau de similaridade $44 \%$ ), estes oriundos dos municípios de Urandi e Verdelândia, respectivamente. O isolado IsV 1 foi o que apresentou as maiores distâncias em relação aos demais isolados avaliados.

A partir da distância média relativa $(37,5 \%$, distância média equivalente em 100), foi determinado o ponto do corte, obtendo-se a formação de oito grupos (Figura 1). O valor cofenético foi alto $(\mathrm{r}=0,96) \mathrm{e}$ adequado, já que $r \geq 0,8$ é considerado ideal e reflete uma boa concordância com os valores de distância genética (BUSSAD et al., 1990). Três grupos foram formados com apenas um isolado Is V1 (grupo I), IsP1 (grupo II) e IsE 5 (grupo III). O grupo VIII foi o que agrupou boa parte dos isolados (13), incluindo os de menor dissimilaridade. Por meio de análise do dendrograma obtido, pôde-se observar alta diversidade genética entre os isolados avaliados e ausência de correlação entre a diversidade genética observada e as origens geográficas dos isolados.

Os resultados obtidos no presente estudo corroboram outros estudos realizados. MOREIRA et al. (2003), ao avaliarem a variabilidade genética entre isolados de $\boldsymbol{M}$. musicola provenientes de diferentes estados brasileiros, mediante a utilização da técnica de RAPD, observaram grande diversidade genética sem correlação com as origens geográficas, sugerindo que esta alta diversidade é devido às condições climáticas, à ocorrência de reprodução sexuada e também à natureza heterotálica do fungo. No estado de Pernambuco, estudo realizado acerca da diversidade genética de M. musicola por meio do uso de marcadores RAPD também demonstrou a existência de uma grande variabilidade genética entre os isolados coletados em nove municípios, com valores de dissimilaridade de 0,67 , também sem correlação com as origens geográficas (MONTARROYOS, 2005). ROCHA (2008) também detectou alta variabilidade genética em 11 isolados de $\boldsymbol{M}$. musicola, provenientes de diferentes regiões brasileiras produtoras de banana, sendo um deles do norte de Minas Gerais, utilizando marcadores SSR. Porém, neste estudo, obteve-se uma separação dos isolados de acordo com sua região geográfica. MOLINA et al. (2001) conseguiu separar 64 isolados de diferentes localidades da Colômbia, de acordo com sua origem, utilizando marcadores SSR. A diferença em conseguir correlacionar ou não de acordo com a origem pode estar relacionado à natureza do marcador, visto que só foi possível separar de acordo com a origem, quando se utilizou marcadores SSR.

A alta variabilidade genética detectada entre os isolados de $\boldsymbol{M}$. musicola no presente estudo e em outras regiões do Brasil, pode ser justificada pelo tempo da presença do patógeno, no Brasil, desde 1944 (KIMATI \& GALIL, 1980) e, no Norte de Minas Gerais, a partir da década de setenta (LICHTEMBERG \& MOREIRA, 2006). Além disso, fatores associados à reprodução sexuada do fungo, às pequenas distâncias geográficas entre os municípios amostrados, à troca

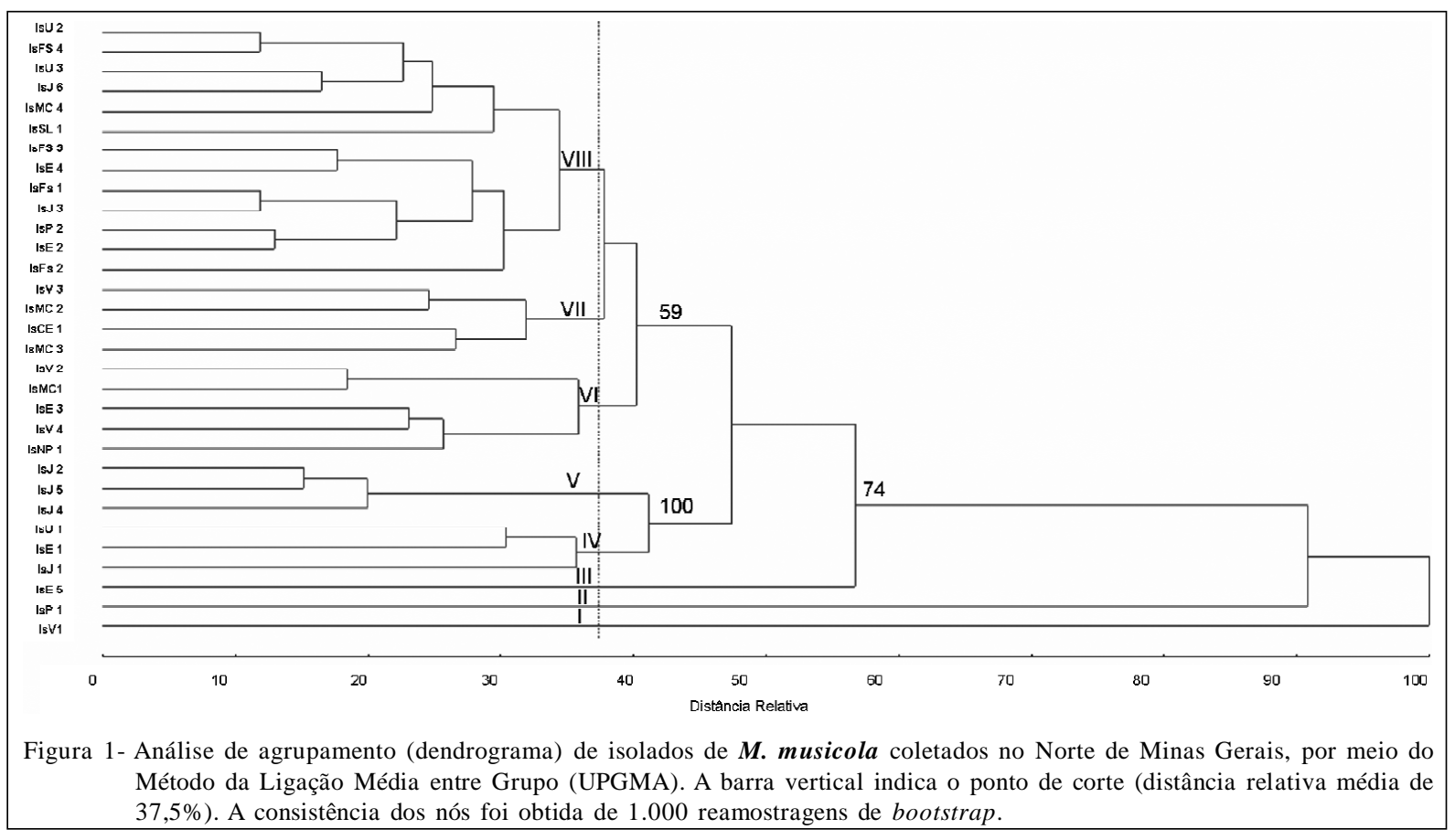

Ciência Rural, v.43, n.1, jan, 2013. 
de material genético infectado entre os produtores, à utilização de cultivares de bananeiras suscetíveis à doença e ao uso indiscriminado de fungicidas colaboram efetivamente para o aumento da variabilidade.

Embora a Sigatoka amarela seja considerada uma das principais enfermidades em bananeira, este é um dos primeiros relatos acerca da variabilidade genética do patógeno no Norte do Estado de Minas Gerais. Os estudos acerca da diversidade genética e o conhecimento dos fatores ambientais que possam estar associados à geração de variabilidade patogênica podem auxiliar significativamente na predição de epidemias, bem como no desenvolvimento de cultivares ou seleção de clones resistentes.

\section{AGRADECIMENTOS}

Os autores agradecem à Fundação de Amparo a Pesquisa do Estado de Minas Gerais e ao Conselho Nacional de Desenvolvimento Científico e Tecnológico $(\mathrm{CNPq})$, pelo apoio financeiro e concessão de bolsas.

\section{REFERÊNCIAS}

BUSSAD, W. de O. et al. Introdução à análise de agrupamentos. São Paulo: ABE, 1990. 105p.

CORDEIRO, Z.J.M. et al.'Preciosa': Variedade de Banana Resistente à Sigatoka-Negra, Sigatoka-Amarela e ao Mal-doPanamá. Revista Brasileira de Fitopatologia, v.30, p.1-5, 2005.

CRUZ, C.D. GENES - versão Windows. Viç̧osa: UFV, 2001. $42 \mathrm{p}$.

DOYLE, J.J.; DOYLE, J.L. Isolation of plant DNA from fresh tissue. Focus, v.12 p.13-15, 1990.

FALEIRO, F.G. et al. Caracterização e diversidade genética de isolados de Phytophthora spp. do cacaueiro com base em marcadores RAPD. Fitopatologia Brasileira, v.29, p.303306, 2004.

FAO. FAOSTAT: Crops-banana. Roma, 2009. Disponível em: <http://faostat.fao.org>. Acesso em: 22 jun. 2012.

JONES, D.R. The distribution and importance of the Mycosphaerella leaf spot diseases of banana. In: WORKSHOP
ON MYCOSPHAERELLA LEAF SPOT DISEASES, 2003, San Jose, Costa Rica. Anais... Montpellier: INIBAP, 2003. p.25-41.

HALKETT, F. et al. Genetic discontinuities and disequilibria in recently established populations of the plant pathogenic fungus Mycosphaerella fijiensis. Molecular Ecology, v.19, p.39093923, 2010.

KIMATI, H.; GALLI, F. Doenças da bananeira Musa spp. In: GALLI, F. Manual de fitopatologia. São Paulo: Agronômica Ceres, 1980. V.2, p.87-101.

LICHTEMBERG, L.A; MOREIRA, R.S. The history and characteristics of the 'Enxerto' banana. In: INTERNATIONAL MeEting ACORbat, 2006, Joinvile, SC. Proceeding... Joinvile: ACAFRUTA, 2006. V.2, p.885-887.

MOLINA, C. et al. Microssatelitte markers for the fungal banana pathogen Mycosphaerella musicola. Molecular Ecology Notes, v.1, p.137-139, 2001.

MONTARROYOS, A.V.V. Análise da diversidade genética e patogênica de Mycosphaerella fijiensis e Mycosphaerella musicola no Brasil. 2005. 182f. Tese (Doutorado em Ciências Biológicas) - Universidade Federal de Pernambuco, PE.

MOREIRA, R.F.C. et al. Caracterização genética de isolados de Mycosphaerella musicola por marcadores RAPD. Summa Phytopathologica, v.29, p.275-277, 2003.

PEREA, I. et al. Genetic diversity of Colombian isolates of Mycosphaerella fijiensis Morelet based on microsatellite markers. InfoMusa, v.14, p.18-21, 2005.

ROCHA, H.S. Epidemiologia da sigatoka amarela, quantificação de fenóis em variedades de bananeiras e análise filogenética de isolados de Mycosphaerella musicola utilizando microssatélites. 2008. 125f. Tese (Doutorado em Fitopatologia) - Universidade Federal de Lavras, MG.

RODRIGUES, M.B.C. et al. Resistência a benzimidazóis por Guignardia citricarpa. Pesquisa Agropecuária Brasileira, v.42, p.323-327, 2007.

RODRIGUES, M.G.V. et al. Banana. Informe Agropecuário, v.32, p.35-48, 2011.

RIVAS, G.G. et al. Founder effects and stochastic dispersal at the continental scale of the fungal pathogen of bananas Mycosphaerella fijiensis. Molecular Ecology, v.13, p.471482, 2004. 